\title{
Library Instruction in the Freshman Orientation Program
}

Mr. Erickson is librarian, Eastern Oregon College of Education, La Grande.

W

ERE THE COllege librarian of 50 years ago suddenly to come to life and be placed in the library wherein she had long since labored, she would probably be as amazed at the expanded services offered, as would be the druggist who, hypothetically, might find himself in a similar state of rebirth upon returning to his store.

In drawing the analogy, however, 1 hope that it can be said that the original purpose of the library has not been obscured as it sometimes seems to have been in the case of the pharmacy. Microfilms, moving pictures, slides, recordings, listening rooms, interlibrary loans and all the other innovations certainly indicate a healthy growth in the services rendered by the library to college students.

Not the least of these innovations is that of library instruction for freshmen. Perhaps innovation is the wrong word, for there has always been library instruction of some kind on an individual basis. It is an innovation only to the extent that it is gradually becoming a well-integrated course of instruction, often required of college freshmen and generally carrying some credit toward graduation.

The question has been raised: Are we probably placing too much emphasis on formal library instruction for college fresh-

${ }^{1}$ Paper presented at the meeting of the Libraries of Teacher-Training Institutions Section, A.C.R.L., Jan. 21, 1949, Chicago. men? Judging by the comments of most of the 6 I librarians who participated in a survey of library orientation programs in American teachers colleges, ${ }^{2}$ which I made last year, I should say that the answer is an emphatic "No!" The fact that $6 \mathrm{I}$ of the 75 librarians queried took time out of busy working schedules to fill out and return the questionnaires indicates more than a casual interest in the subject.

The voluntary comments accompanying the returns, however, evinced a considerable interest in methods of improving library instruction. Librarians seemed quite generally agreed that more needs to be done. This viewpoint manifested itself again in letters received from interested librarians after the publication of the findings of the survey last fall. One individual wrote to say that she had received requests from colleges in 14 states for copies of her library handbook, which I had mentioned incidentally in the article. While interest alone does not prove a need, it certainly suggests an agreement among librarians that we should do more with library instruction as a part of freshman orientation than we are doing.

Perhaps the most serious deterrent to successful library orientation programs, as expressed in the questionnaires returned, is insufficient library personnel. In many cases what began as promising programs of library instruction were either dropped com-

2 Erickson, Walfred, "Library Orientation Programs in American Teachers Colleges." Wilson Library Bulletin, 23:62-63, September 1948 . 
pletely or were reduced to ineffective routines as enrolments mushroomed and library staffs remained relatively small. Many of the comments indicated that library instruction was too frequently a casualty when some services had to be curtailed within the institution. Disinterest of faculty members was cited as another problem facing librarians in formulating an integrated program of library orientation. Effective library instruction cannot be achieved without the cooperation of classroom instructors.

Programs designed to instruct college freshmen in the use of the library follow roughly three patterns. First, there is the course that is established in the curriculum as a unit complete in itself, usually a onecredit course, sometimes required, sometimes not. A professional librarian is almost always employed to teach this course, and librarians who have utilized this method have generally found it successful. Where it is an elective course its weakness is that it reaches too few students and frequently misses many students who need it most.

A second plan of library instruction for freshmen is that which is fitted into a general orientation course. When handled in this way it frequently involves merely a one-hour lecture to new students, perhaps combined with a tour of the library. The number of hours devoted to library instruction with this method depends generally upon the size of the library personnel and the extent to which the committee in charge of freshman orientation is library-minded. Credit toward graduation is given in many instances insofar as the general orientation program is a credit-bearing course. There was a wide variance in the measure of success of this type of program. Some were admittedly a waste of time and others indicated very satisfactory results.

A third method used in some teachers colleges is to teach the use of the library in the regular freshman composition classes, usually preparatory to working on a term project. In some cases the individual English instructor handles it herself and frequently the librarian is called in to assist. This procedure seems to prove quite successful, especially where members of the library staff have the time to assist with the instruction, and where the English staff is really interested and concerned in effective library instruction.

In all the methods cited the library serves as a laboratory and a great deal of teaching is carried on as the library staff works with individuals who have difficulty finding what they need in the library.

In studying the returns from those colleges having some kind of library orientation program, I was interested to observe that while hours devoted to library instruction varied from one to 18 , the instruction generally covered the same library subjects. Most of the schools attempted to teach the general arrangement of the library; library rules, schedule of hours, etc.; the broad classes and some subdivisions of a classification system; the use of the card catalog; the use of at least two periodical indexes; and varying numbers of standard reference works. It goes without saying that instruction was extremely superficial in some cases.

All of us are interested in learning what constitutes a program of library instruction that is both feasible and effective for the typical teachers college. In considering this question I am particularly interested in a program that will fit the needs of the small and medium-sized colleges, although there is no good reason why an adaptation of what I have to suggest could not be used in the larger college.

Looking at the problem realistically and recognizing the fact that most library staffs are already overtaxed with ever-increasing duties, I would like to suggest a program of freshman library instruction in which 
some of the teaching could be handled by other faculty members. Perhaps a combination of two of the methods mentioned earlier would work out satisfactorily. Instruction could begin as a part of the general orientation program and could then be followed with a unit in the English composition classes. Concurrent with this, of course, would be incidental library instruction, which ought to be a part of all classroom activity, and directed laboratory experience in the library itself.

Let us assume that the college for which this course is designed has a one-credit course in freshman orientation which meets once a week for the period of one quarter, or more often for a shorter number of weeks, and that the orientation committee is library-minded and has allotted five hours of this program to the library staff to lecture, demonstrate and discuss matters of library practice with the new students.

Instruction would probably cover the same material now being covered with varying degrees of success in selected institutional programs. Depending upon the size of the class and the available professional library staff, the class might be divided into sections for instruction in small groups. Where this is not practical-and it is more than likely that a library staff could not find the time for meeting many small groups-perhaps a breakdown of the group could be managed at least for the first meeting, which should be a library tour in which the general arrangement of the library, circulation routines, etc., could be explained to the students.

The ensuing meetings might well be used to discuss the use of the card catalog and its component parts, periodical indexes-at least the Education Index and the Readers' Guide - and some of the standard reference works. Where the emphasis would be placed in the latter catagory would depend largely upon local institutional needs.
Concise problems should be in the hands of the students before each lecture so that practice work might be done in the library on the basis of the day's discussion. I realize that the mass freshman invasion of the library can wreak havoc with orderly library routine and that consequent "cooperative study" might result in little learning for some of the group, but I am sure that many students will benefit from the exercise.

In such a brief course of library instruction there must necessarily be some abridgement of formal textbooks if they are to be used at all. The most common practice seems to be to place formal texts on reserve and to use them as supplements to handbooks, pamphlets or mimeographed materials. The two inexpensive pamphlets Time Savers; the Periodical Indexes and So This Is the Catalog, published by the H. W. Wilson Company, are excellent helps. Then if a concise, interesting and practical handbook can be printed or mimeographed locally, it can often be of more assistance to the student than most formal textbooks.

As a technique of instruction the librarian would do well to utilize all available audiovisual materials to supplement the teaching materials. While most films and filmstrips are designed for elementary and secondary school children, some can be adapted easily to college situations. Notable among these and especially useful in the type of library instruction I am suggesting is the filmstrip Use Your Library recently announced by the American Library Association. It demonstrates very clearly the fundamental features of the card catalog, periodical indexes and some standard reference works.

Some colleges are producing their own films and filmstrips with a good deal of success. What they lack in artistic excellence they perhaps more than make up in local interest. The article "Look, Listen, 
and Use," by Emma G. Parsons and Marjorie Tate, which appeared in the September 1948, issue of the Wilson Library Bulletin, tells of the success of a locally-made film on the campus of Fairmont State College at Fairmont, W.Va.

At the conclusion of the five library lectures in the general orientation program, the problem of formal library instruction could be passed on to the English department where in freshman composition classes assignments could be made to apply the information gained during the brief preceding period of orientation. A sympathetic and interested English department might be prevailed upon to reserve the unit on the use of the library, which most freshman English texts include, until preliminary library instruction has been given. The librarian in conference with the head of the English department could determine where the emphasis might best be placed in this unit to satisfy the student's library needs. During the course of this unit previous instruction can be reviewed, assignments made to direct students into the library, and specific questions answered that might not have been clear at the close of the meetings of the larger groups. The unit could logically conclude with a term project that would give the students ample opportunity to apply their knowledge of library practice.

Whatever a college decides to do toward instructing new students in the use of the library, however, the freshman orientation course seems to me a good point of departure, and carrying the instruction into the English classes with specific library assignments can be a logical implementation of the library learning accomplished in the earlier meetings.

A program of library instruction as a part of general freshman orientation, as I have briefly outlined it, may or may not be feasible in most teachers colleges. I feel certain, however, that adapted to local situations according to the wisdom of the librarian and with the support of libraryminded orientation committees and English instructors, it can be carried out successfully. It will take time and effort to achieve good results and the librarian must be a diplomat of no mean ability to integrate her program with that of the English department and continue in rapport with its members to the end of the course.

At any rate, while the old adage "The Lord helps them who help themselves" may bear considerable truth, the library staff and college faculty must do their part toward helping the young freshman orient himself in a new and bewildering situation.

\section{Motion Picture Catalog}

Two new features have been added to the latest number of the Motion Picture Catalog. One is an index to films arranged under such categories as feature pictures, animated cartoons, newsreels, television films, classroom films, industrial films, and $16 \mathrm{~mm}$. films of general interest; and the other is a list of motion pictures on which copyright was renewed during the period January-June 1949. Formerly it has been necessary to buy part I4A of the Catalog of Copyright Entries in order to get renewal information.

As in the earlier issues of the Catalog, the main list is arranged by title with each entry giving full information about each picture, including usually a summary of the content of the film. The index lists producing companies, releasing agents, copyright claimants, sponsors and authors of literary works used as story sources.

It is available from the Copyright Office, Library of Congress, Washington 25, D.C., at $\$ 1.00$ per year or 50 cents per number. 